\section{What cuckoo's}

Vienna

THE Soviet resignation from the World Psychiatric Association (WPA), followed by the resignations of the Bulgarian, Czechoslovak and Cuban psychiatric associations, cast a shadow over the Seventh World Congress on Psychiatry here last week. These resignations did not, however, herald a general walk-out of the Socialist bloc as had been feared. Romanian and Polish psychiatrists attended the Congress but not the meeting of the WPA executive. However, the Hungarians came in force with more than forty people, mainly interested in the anomalously high suicide rate of Szeged county, while the East Germans made a spirited stand at the general assembly to keep "politics" out of the association.

The reason for the Soviet resignation from WPA was the well-documented allegations of political abuse of psychiatry to repress dissent in the Soviet Union. Unfortunately, at one press conference, the outgoing WPA secretary, Dr Peter Berner, gave the impression that the problem was simply a divergence of theory. In fact, the theory of "creeping schizophrenia" ( a disease unknown outside the Soviet Union) promulgated by Dr Andrei Szeshnevskii is frequently cited by the Soviets to justify

\section{nest next?}

"political psychiatry"; but, as Dr Anatolii Koryagin, now serving a seven-year prisoncamp sentence for an article in The Lancet revealing the dark facts of Soviet political psychiatry showed, such theories are frequently a facile "justification" for morally untenable practice.

The Soviet resignation was accepted with "regret", and a motion from the United Kingdom Royal College of Psychiatrists was accepted with an overwhelming majority, assuring the Soviets that they were welcome to rejoin as soon as they can prove they have abandoned doubtful practices.

The issue of psychiatric ethics cut deeper than this political issue - or indeed, the converse allegations of malpractice and neglect in "black" mental hospitals in the Republic of South Africa. Behind the frankly commercial aspects of much of the conference the ethical issues of psychiatry constantly manifested themselves. In particular, papers were presented on the apparent conflict between patient confidentiality and the need for comprehensive epidemiological surveys, the need to relate psychiatric and psychotherapeutic treatment to the cultural background of the patient and the problems of patient consent in carrying out double-blind tests on new psycho-pharmacological agents. Vera Rich

\section{UK ministry decrees drug price cut}

THE Association of the British Pharmaceutical Industry (ABPI) said it was "shocked"' after Mr Norman Fowler, Secretary of State for Social Services, last week persuaded industry representatives to accept a $£ 25$ million reduction in the National Health Service (NHS) drugs bill for the current financial year. ABPI

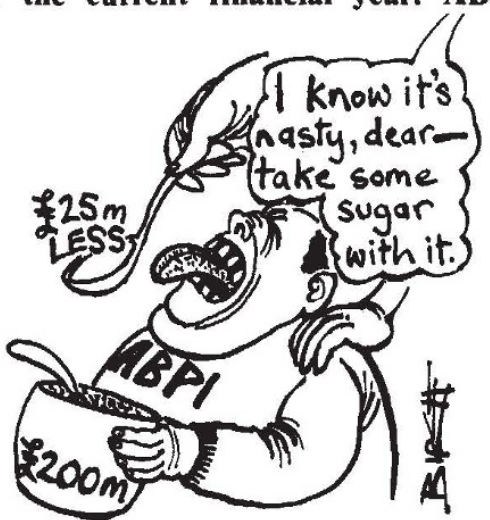

warned that "such repressive measures if continued or extended will damage investment confidence leading to a reduction of research activity".

Mr Fowler's request was part of $a £ 1,000$ million package of expenditure cuts and asset sales agreed by the Cabinet. The savings on the NHS drugs bill, now running at about $£ 2,000$ million per year, will be achieved by paying suppliers an average of
2.5 per cent less and freezing all prices until next April. ABPI members spent $\mathbf{1 4 0 0}$ million on research in Britain last year, and 60 per cent of their sales revenues comes from the home market; profits on sales to NHS amounted to $£ 200$ million.

ABPI says that the new cuts fall outside the scope of the Pharmaceutical Price Regulation Scheme, which sets individual profit targets - calculated on capital employed - for suppliers to NHS. But the association may have worse surprises in store. The House of Commons Public Accounts Committee recently suggested a much larger cut in the average profit allowed, and the Department of Health and Social Security is now conducting a "major review" of the whole subject. Last year, nine companies exceeded their profit targets, although less than $£ 1$ million of the total $\mathbf{2 3 3}$ million excess is likely to be reclaimed; the rest falls within a 10 per cent "grey area" over the targets that is meant to provide an incentive to efficiency and exports. This method of regulating profits has been criticized for penalizing those companies whose research efforts are more that Mr Fowler will make changes designed to encourage "generic" prescribing, recommended earlier this year by the Greenfield report but on which the governsuccessful. The industry is also worried ment has not yet acted. Tim Beardsley
African famine

\section{Can science help in time?}

THE green revolution is still racing against the threat of famine, according to a group of leading agriculturalists meeting in London last week. Africa, for example, faces "mega-disaster" in 10-15 years and not in the "comfortable middle distance". The Interunion Commission on the Application of Science to Agriculture, Forestry and Aquaculture (CASAFA), an offspring of the International Council of Scientific Unions, is seeking to drum up serious interest in realistic practical questions which might nevertheless be of some assistance.

CASAFA, meeting to define its first research programme, showed its pragmatic approach by rejecting 57 out of a list of 64 project proposals. It is not that there is a lack of money. Sir Charles Pereira, a CASAFA member, said that the aid agencies are swamped with good intentions but not with good ideas and that one of CASAFA's objectives is to sort out "the bids based on pure optimism from those based in some fact".

The priority list agreed last week includes "allelochemicals" - low molecular weight compounds, on one case simply oxalic acid, which seem to be given off by some plants (including some rice species) to repel insects; the physiology of salt tolerance in rice; soil physics and aggregation of soils in rice fields; the link between tolerance to heat and winter hardiness in wheat; flower and fruit fall in potato; the symbiosis of Frankia species (nodule-forming nitrogenous bacteria) with Casuarina, a widespread tropical and semi-tropical tree whose many varieties can grow in conditions from desert to salt water and which burns fiercely; and the control of Striga, a parasitic weed now badly affecting Africa.

CASAFA's list is strictly a list of priorities. Other topics are also worthy of support. The physiology and pathology of aquaculture species is little known but important, especially because the protein content of fish does not denature as easily as meat. For Pereira, the large reserves of volcanic rock phosphate are a key issue because there are no facilities to test them in the tropics.

As for the continued dependence of the green revolution on fertilizers, the CASAFA group is pessimistic. High cropping inevitably requires high feeding, and the genetic engineering solution seems a long way off, and anyway might absorb so much energy from the plant that crops would be reduced. So CASAFA pointed the finger only in one direction: at the energy of the flare-off from Arabian oil wells, which could provide $50-100$ per cent of nitrogen-fixation needs of the developing countries if only they were fully used.

Robert Walgate 